\title{
Settlements and dwellings of Karachais and Balkars
}

\author{
Aminat Sultanova* and Zalina Unezheva \\ Kabardino-Balkarian State University named after Kh.M. Berbekov, 360004, Nalchik, Russia
}

\begin{abstract}
This article is devoted to one of the underdeveloped issues of the material culture of the Balkar and Karachai people - dwellings and settlements, which are the main components in human life support. The traditional dwellings of the Balkars and Karachais were distinguished by their special features that had been developed over the centuries in a peculiar historical and geographical setting. The paper gives a general description of the Balkar and Karachai dwellings.
\end{abstract}

\section{Introduction}

Balkaria and Karachay represent an almost continuous mountain range of the Central Caucasus, therefore their settlements are mountainous. In mountainous conditions, the main building material for the construction of dwellings was a stone of various breeds and timber. If stone, as a building material, was available in all gorges, then timber was in abundance only in the upper reaches of the Kuban and Malka, in the Baksan gorge, in this regard, in the Chereksky, Khulamo-Bezengiysky and Chegemsky gorges, the walls of dwellings were built of stone, and in the Kuban and Baksan gorges - in a combination of stone and timber, or only from timber.

The traditional dwelling was a stone hut with a flat earthen roof. Many dwellings were cut into the very massif of the mountain slopes. Therefore, in the process of preparing the site for the dwelling, it was necessary to make a ledge, the stones removed from the slope were used for laying the walls and the earth for filling the roof.

The facades of the dwellings were facing south and were in the sun for most of the day.

\section{Settlements}

Geographic conditions directly influenced the layout of the Balkar and Karachai settlements. The settlements were located both on the steep slopes of the gorges, that is, on the road (the dwellings were arranged in ledges or tiers, so that the roofs of the row lying below served as yards for the one lying above, etc.), and on more or less flat terrain. Since most of the villages of Karachay and Balkaria were located in narrow and deep valleys, where the mountain slopes in places came close to the channel of small rivers and springs,

\footnotetext{
* Corresponding author: asultanova2801@yandex.ru
} 
all these villages had broken and curved outlines, obeying the direction of the rivers and the terrain.

The houses located in the terraced row in the Karachay-Balkarian villages were, as it were, under one roof, having climbed onto the roof of a house at one end of the village, it was possible to freely walk to the other end of the village. These same roof-terraces often served as roads.

For settlements located on a more or less flat terrain, crowded buildings were characteristic, and the streets in them were crooked and narrow, that only some of them could drive a mountain cart [1].

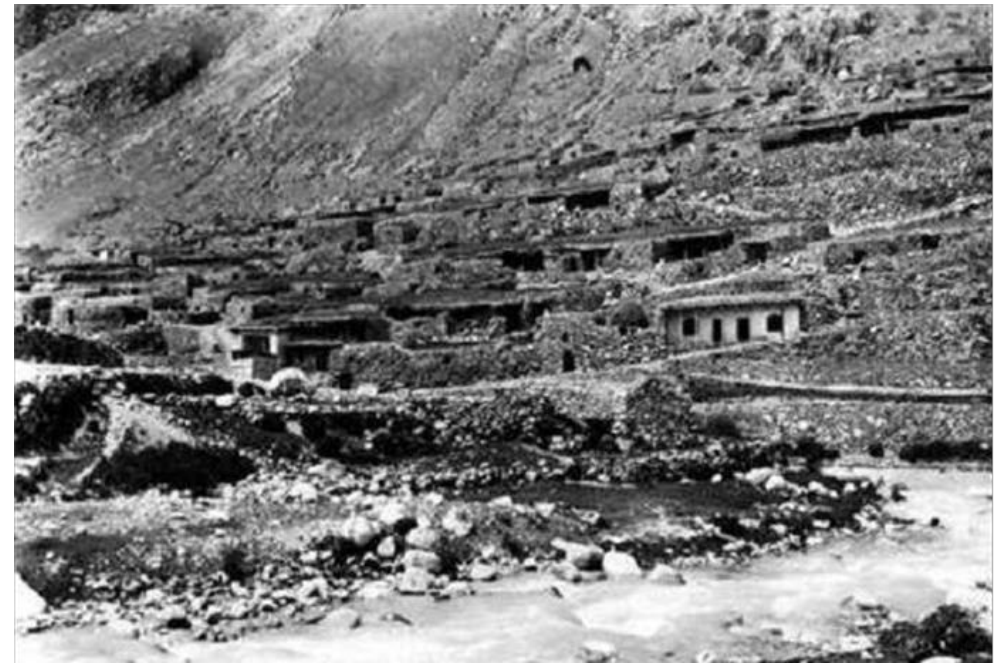

Fig. 1. Shabby location of the village among Karachais and Balkars

The villages gathered in groups and formed quarters. In the existence of quarters, it is not possible to see the influence of only topographic conditions, which made it possible to build huts only on the most convenient parts of the valley for this purpose; the main reason must be considered, to be generic. Each quarter is inhabited by only one family, and got its name after this family [2].

Huts in the neighborhoods were located without any order.

The size of the quarters depended on the number of members of a given surname. N.P. Tulchinsky at the beginning of the XX century wrote: "Almost every village in mountain societies constitutes a family community, bearing one common surname and descending from one ancestor, but in everyday life, each courtyard lives separately, ruled by an elder in the house." [3].

\section{Dwelling. Manor}

The plan for the estate development, the size and location of the auxiliary premises - all this was in close connection with the everyday life of the economic structure of the people.

The estates located in more flat areas were spacious. In the mountains, two types of estates were distinguished - with vertical and horizontal buildings.

The complex of the estate of a large family included: the main one - the central dwelling, in fact a large house; living quarters adjoining it, attached as new married couples were formed (Fig. 2); awnings in front of living quarters; sheds and premises for sheep and cattle that remained at the farmstead, and, finally, the yard - the space between the listed buildings [4]. 


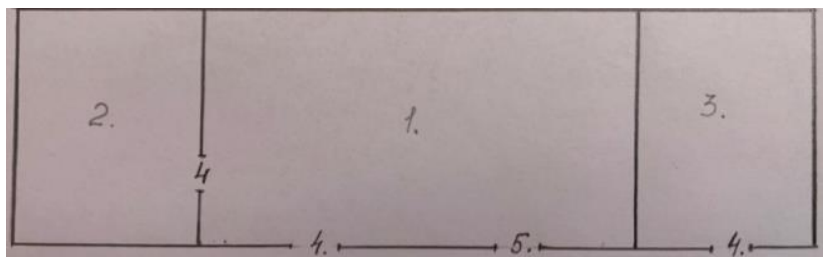

Fig. 2. The plan of the huts. 1. Big house. 2. Pantry. 3. Otou (room). 4. Entrance doors. 5. Window

\subsection{Big house}

The big house was the main building of the estate and consisted of a single-chamber dwelling, where all family members spent the night in one room. In most cases, the large house was low and had the shape of a square or elongated rectangle, built of pine logs. The laying of the logs was rough, the wide gaps between them were covered with clay. The roof of the huts was earthen (up to a meter), flat, slightly convex or gable and densely overgrown with grass.

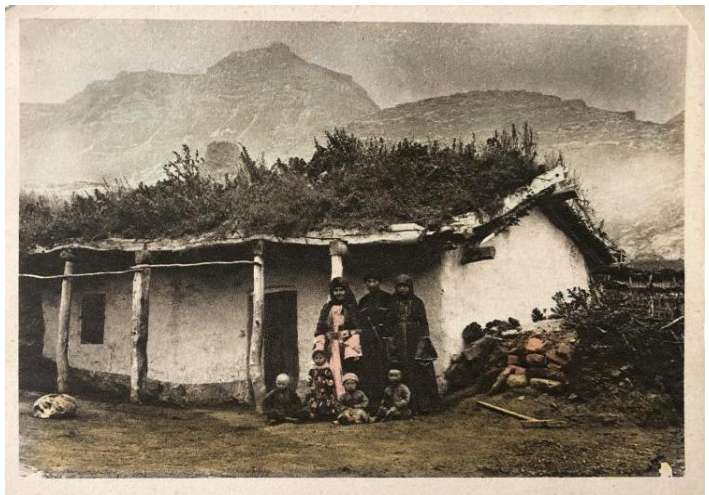

Fig. 3. Postcard. Karachaevsk Hut

Along the front facade, the roof was pushed forward, thus forming a canopy, which was supported by timber posts; under this canopy, closer to one end of the hut, a rectangular hole was cut for a door that led to separate rooms of the huts (Fig. 3). The doors were very low, single or double doors and opened inward. The oldest types of dwellings, both clay and stone and log houses, for the most part have no or almost no window openings [5]. Light penetrated through the fireplace smoke hole. A round, tapering upward wattle fence, coated with clay and whitewashed, was installed over the opening of the roof (Fig. 4).

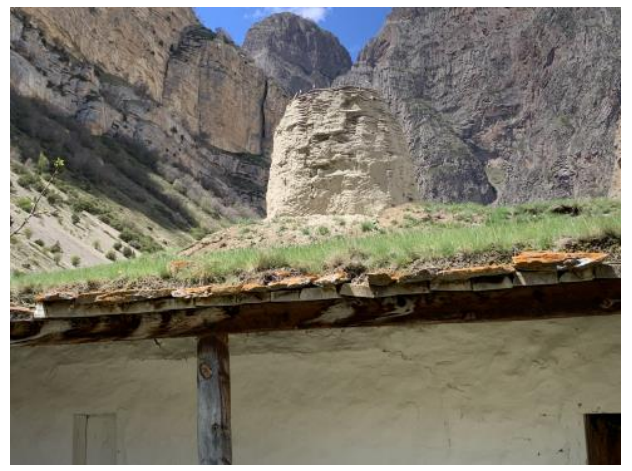

Fig. 4. Smokebox in K. Kuliev's hut in the village of Eltyubu 
The hut was usually divided into 3 sections: male, female and pantry. The female half was located between the main dwelling and the household yard and had an entrance separate from the main dwelling.

\subsection{Residential outbuildings}

Usually next to the main house otou was traditionally located - a room for newlyweds. Otouu was sometimes located under the same roof with the main dwelling (ullu yui). In terms of its structure, the otou did not differ much from the main dwelling, only it was much smaller than the ullu yui. In otou, as a rule, no hearth was built, and it was not heated. There was no pantry [6]. Otou usually had the shape of an elongated rectangle.

All the doors of the living quarters went out into a common courtyard, from which there was only one exit to the street - through powerful double gates that were tightly closed.

\subsection{Kunatskaya}

The Balkars, as well as the Karachais, had two places for receiving guests: one was near the hearth in the "ullu yui" (big house), and the other was in a separate attached room - the kunatskaya [7].

Kunatskaya - a special room for guests - was widespread throughout the North Caucasus.

Among the Balkars and Karachais, the kunatskaya could be located separately in the courtyard in the form of a special structure, or it could be part of a common residential building, which had a separate entrance to the common house. The arrangement of a kunatskaya outside the territory of the estate, as was the case with some peoples of the North Caucasus, was not practiced by the Karachais and Balkars, since it did not meet the etiquette standards of hospitality.

\section{Yard (arbaz)}

A feature of ethnographically studied Karachai dwellings and settlements is the presence of covered courtyards. The latter are not in the houses of the Balkars and other neighboring mountain peoples [8].

Until the second half of the 19th century noble people owned closed estates. Log buildings, consisting of several residential and utility rooms, were built inside a covered courtyard.

Arbaz is a very massive structure of solid logs up to $2 / 3$ meters thick, which most often had a rather irregular shape. Residential and household buildings, located in the form of a closed square, rectangle or polygon, constituted a complex of a closed courtyard (arbaz). The entrances from all of these rooms led to the inside of the polygon. The formed closed courtyard was covered with a heavy earthen roof. The powerful roof beams rested on especially thick pillars and, necessarily, on a few badges. The roof sloped slightly in all directions, as did the roofs of polygonal structures. Arbaz had one (rarely two) rather wide entrance, usually closed by massive doors. The height of the arbaz was up to 4-5 meters [9].

Thus, the arbazes were a complex, monumental, durable structures.

Traditionally, the houses from the side of the street were closed with high fences. Various types of fences are known - from stacked stones, lath fence, wattle. 


\section{Conclusion}

Thus, we come to the following conclusions.

1. The greatest influence on the layout of the Balkar and Karachai villages was exerted by the physical and geographical conditions.

2. There were two large types of settlements. One of them was located on steep mountain slopes, ragged, the second type was located in gentle, relatively flat highmountain valleys.

3. The main and determining factor in the dwelling formation of the Karachais and Balkars was the local specific environment.

4. According to the material used, the Karachai and Balkarian houses should be subdivided into several types: timber log house, stone and combined.

5.Karachay and Balkar dwellings were distinguished by their monumentality, complexity and quality of construction.

\section{References}

1. Kh.-M. A. Sabanchiev, Karachais. Balkars 196 (2014)

2. I.S. Shchukin, Materials for the study of the Karachais 44-45 (1913)

3. N.P. Tulchinsky, Five Mountain Societies of Kabarda 179 (1903)

4. E. B. Bernstein, Architecture of the Balkar People's Dwelling 12 (1993)

5. V.P. Kobychev, New and traditional features in the modern dwelling of the peoples of the North Caucasus 183 (1978)

6. K.M. Tekeev, Karachais and Balkars. Traditional life support system 220 (1989)

7. Yu. N. Asanov, Settlements, dwellings and outbuildings of the Balkars 74 (1976)

8. I.M. Miziev, Balkars and Karachais in historical monuments 107 (1981)

9. L.I. Lavrov, Karachay. Historical and ethnographic sketch 136 (1978) 